\title{
Cell Division Control Protein 6 Homolog
}

National Cancer Institute

\section{Source}

National Cancer Institute. Cell Division Control Protein 6 Homolog. NCI Thesaurus. Code C18044.

Cell division control protein 6 homolog ( $560 \mathrm{aa}, \sim 63 \mathrm{kDa}$ ) is encoded by the human CDC6 gene. This protein is involved in the mediation of DNA replication. 